\title{
CHRONOSTRATIGRAPHIC SEQUENCE OF SANTUARIO DELLA MADONNA CAVE (CALABRIA, SOUTHERN ITALY): AMS RADIOCARBON DATA FROM A NEW EXCAVATION AREA
}

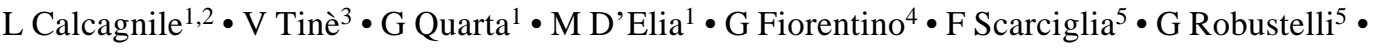 \\ M Abate ${ }^{5} \cdot$ M F La Russa $^{6} \cdot$ A Pezzino $^{6}$
}

\begin{abstract}
The Santuario della Madonna Cave, located near Praia a Mare (Cosenza), along the northwestern coast of Calabria (southern Italy), has an impressive stratigraphy, with occupation phases spanning from the late Paleolithic to the advanced phases of the Middle Bronze Age. Recently, a new excavation area has been opened in the cave from which shortlived vegetal remains were sampled and submitted for accelerator mass spectrometry (AMS) radiocarbon dating. The aim of this study was to define an accurate chronology of the different cultural aspects and to explore the potentialities resulting from application of advanced statistical tools for ${ }^{14} \mathrm{C}$ data analysis in such a context.
\end{abstract}

\section{INTRODUCTION}

Since its early development, the radiocarbon dating method has had a profound impact in various research fields. Archaeology and earth sciences are examples of such disciplines where the method has had revolutionary implications. In archaeology, the ${ }^{14} \mathrm{C}$ dating method has been impacted by developments in the field of calibration (e.g. Reimer et al. 2004), in the introduction of accelerator mass spectrometry (AMS) for ${ }^{14} \mathrm{C}$ detection and, more recently, in the developments of refined advanced statistical tools for the analyses of multiple ${ }^{14} \mathrm{C}$ ages (e.g. Bronk Ramsey 2009). State-ofthe art AMS spectrometers and sample processing laboratories are now routinely able to measure milligram (or even submilligram) samples, with precision levels of about $0.3-0.4 \%$, and with instrumental sensitivities of about $10^{-16}$. In archaeology, all these technical advancements resulted in the possibility of a more careful selection of the samples to be submitted for ${ }^{14} \mathrm{C}$ dating and the ability to have a large number of ${ }^{14} \mathrm{C}$ determinations from the same context. At the same time, advanced statistical tools, many based on Bayesian approaches, were made available (Buck et al. 1991; Bronk Ramsey 1995) to aid in analyzing large sets of ${ }^{14} \mathrm{C}$ dates and to properly use archaeological or stratigraphic information as statistical constraints for their analysis (Bayliss 2009).

We present the results of AMS ${ }^{14} \mathrm{C}$ dating analyses carried out on short-lived vegetal remains selected from a new digging area at the Santuario della Madonna, a natural cave located near Praia a Mare (Cosenza), along the northwestern coast of Calabria in southern Italy. The excavations carried out in the 1960s by the University of Rome revealed an impressive stratigraphy (Figure 1), with several layers related to human occupation of the cave, from the late phases of the Paleolithic Age until the advanced phases of the Middle Bronze Age. In fact, the stratigraphy of the Santuario della Madonna Cave has been one of the key sites traditionally used, since the 1960s/70s, for reconstruction of the different chronocultural phases of southern Italy prehistory (Skeates and Whitehouse 1994; Pessina and Tinè 2008). This study aimed to define an accurate chronology of the different cultural phases and to explore the potentialities resulting from the application of advanced statistical tools for the analysis of the ${ }^{14} \mathrm{C}$ data in such a context, and contributing to refine the absolute chronology for Italian prehistory.

${ }^{1}$ CEDAD (Centre for Dating and Diagnostics), Department of Engineering of Innovation, University of Salento, Lecce, Italy. ${ }^{2}$ Corresponding author. Email: lucio.calcagnile@unisalento.it.

${ }^{3}$ Soprintendenza Speciale al Museo Nazionale Preistorico Etnografico "L. Pigorini,” Roma, Italy.

${ }^{4}$ Laboratory of Archaeobotany and Palaeoecology, Department of Cultural Heritage, University of Salento, Lecce, Italy.

${ }^{54}$ Dipartimento di Scienze della Terra, Università della Calabria, Arcavacata di Rende (Cs), Italy.

${ }^{6}$ Dipartimento di Scienza Geologiche, Università di Catania, Italy.

(C) 2010 by the Arizona Board of Regents on behalf of the University of Arizona

Proceedings of the 20th International Radiocarbon Conference, edited by A J T Jull

RADIOCARBON, Vol 52, Nr 2-3, 2010, p 408-414 


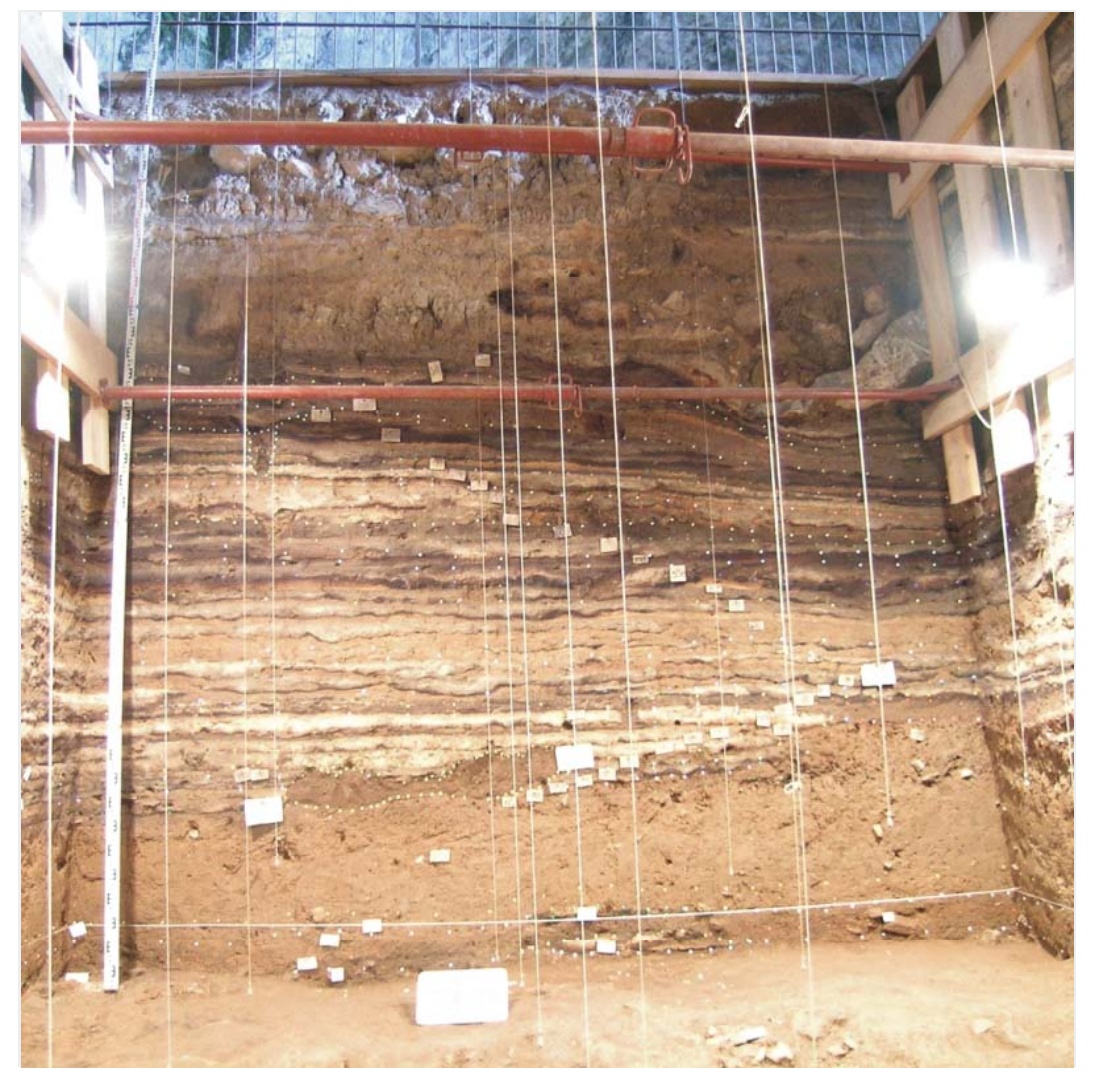

Figure 1 Stratigraphy of the Santuario della Madonna Cave

\section{ARCHAEOLOGICAL INFORMATION}

The Santuario della Madonna Cave represents part of a karstic system, developed in Meso-Cenozoic dolomite-marly limestone and reshaped by the sea during the Quaternary. The single, large room of the cave (over $2000 \mathrm{~m}^{2}$ wide and $15 \mathrm{~m}$ height) has been settled repeatedly by humans from the late Upper Paleolithic to historical times, as shown by the systematic archaeological excavations carried out since the 1960s.

Starting from 2002, a new excavation area has been opened near the NW wall of the cave. Human and animal bone fragments, together with various kinds of stone and pottery artifacts, post-holes, hearth remains, and residues of in situ burning were recovered and used to study the human behavior and practices in the framework of the site and surrounding natural landscape evolution.

The stratigraphy of the studied area is shown in Figure 2. Under the first layer, immediately below the surface and covered by a modern cemetery, 4 main horizons can be recognized in the new stratigraphic sequence:

- Horizon II. The upper levels belong to the Middle Bronze Age, phases 1-2 (the "Proto-Appenninic" cultural aspect) and 3 (Appenninic). These are the richest layers in the whole sequence, showing clear anthropic paleo-surfaces, with several post-holes of possible huts for livestock holding. These layers are followed by subtle levels with typical Laterza culture pottery (Late 


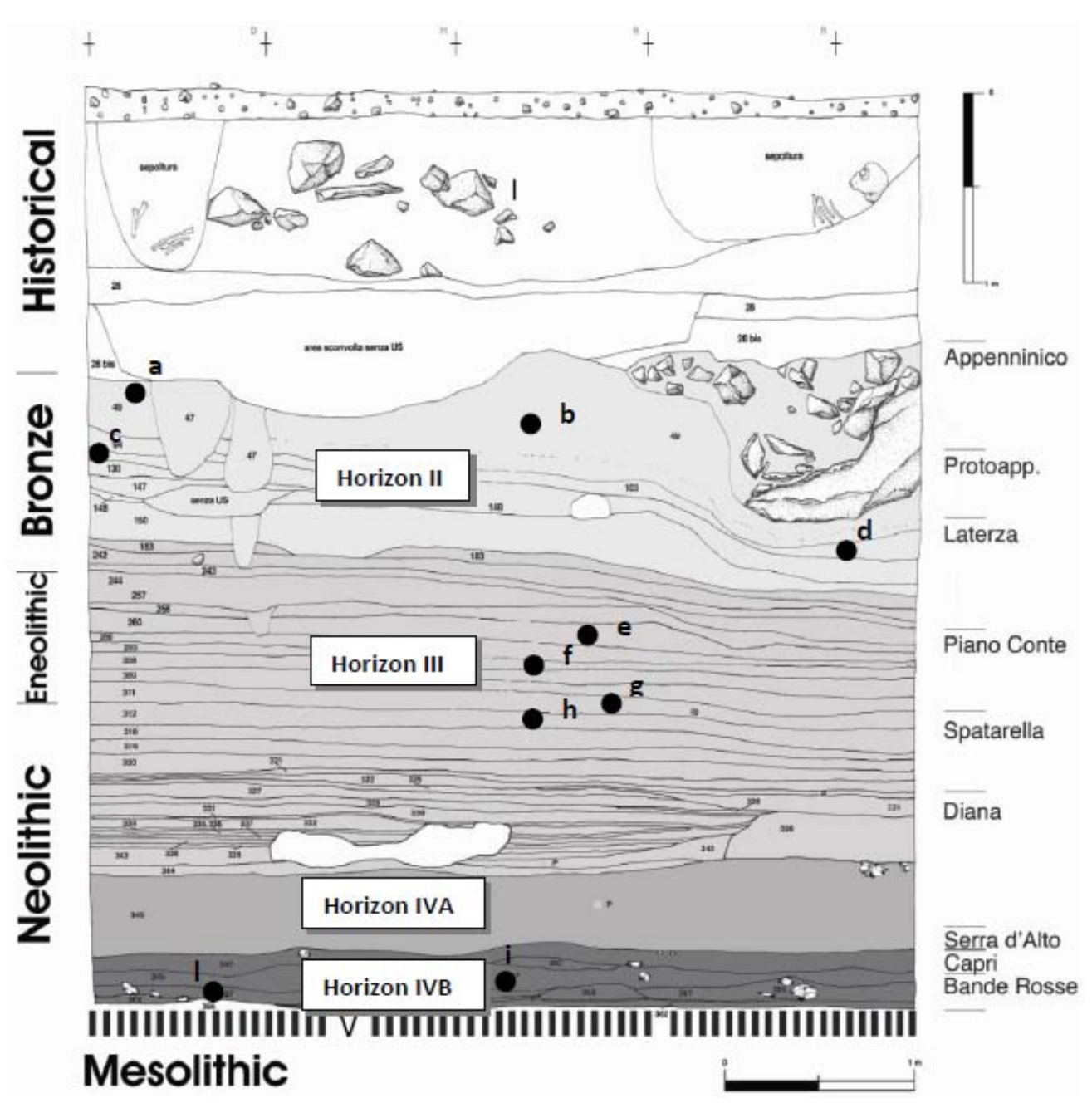

Figure 2 Stratigraphy of the new digging are in the Madonna Cave

Chalcolithic-Early Bronze Age). Archaeological, botanical, and faunal remains suggested an intense anthropic development of the cave during these phases.

- Horizon III. Below these layers, only thin strata were found, showing a peculiar two-fold blackand-white model of soil deposition. The small amount of pottery recovered belongs to the Early Chalcolithic (Piano Conte style) and Late Neolithic (Diana style) age. The dramatic decrease in the botanic record and the weak structural and cultural evidence show clearly the low degree of human frequentation of the cave in this period.

- Horizon IVA. This horizon is characterized by a yellowish clay formation, without any visible features. A few pottery sherds belong again to the Late Neolithic (Diana style) or to the evolved phases of the Middle Neolithic (Serra d'Alto style). The homogeneous formation model and scarcity of the biological and cultural record inside this stratum clearly indicate a hiatus in human occupation of the cave.

- Horizon IVB. The bottom Neolithic level, US 362, contains a great amount of the typical "Red Stripes" (Bande Rosse) pottery from earlier phases of the Middle Neolithic in southern Italy. 
Several firing and draining structures in this stratum suggest direct use of the cave by Neolithic people for living and producing purposes, after the hiatus following the Late Paleolithic or Mesolithic life cycle. The upper surface of this horizon (V) was recovered during the last excavation campaign in the site carried out in 2006.

\section{MATERIALS AND METHODS}

Eleven samples were selected from stratigraphic units spanning the Bronze Age to Mesolithic levels. In Table 1, the samples are listed together with their locations within the strata as shown in Figure 2. Short-lived samples, identified through paleobotanical analysis, were selected for AMS ${ }^{14} \mathrm{C}$ dating analyses, which were carried out at CEDAD (Centre for Dating and Diagnostics) of the University of Salento (Calcagnile et al. 2004). The samples were prepared by the standard chemical processing employed for vegetal remains and aimed at the removal of contaminants and essentially consisting in alternate acid-alkali-acid (AAA) washes (D'Elia et al. 2004). Conversion of the purified sample material to carbon dioxide was done by combustion at $900{ }^{\circ} \mathrm{C}$ in sealed quartz tubes. The extracted carbon dioxide was then converted into graphite by catalytic reduction using $\mathrm{H}_{2}$ as reducing agent and iron powder as catalyst. ${ }^{14} \mathrm{C}$ measurements were carried out at CEDAD on its 3MV HVEE 4130HC Tandetron accelerator (Calcagnile et al. 2005). IAEA-C6 (sucrose) and IAEAC4 (subfossil wood) standards were used for normalization and background correction, respectively. The measured ${ }^{14} \mathrm{C}$ concentrations were corrected for mass fractionation by using the $\delta^{13} \mathrm{C}$ term measured on-line with the AMS system with conventional ${ }^{14} \mathrm{C}$ ages calculated according to Stuiver and Polach (1977).

Table 1 Analyzed samples and uncalibrated ${ }^{14} \mathrm{C}$ ages.

\begin{tabular}{|c|c|c|c|c|c|}
\hline Sample ID & $\begin{array}{l}\text { Statigraphic } \\
\text { unit }\end{array}$ & $\begin{array}{l}\text { Sampling } \\
\text { position }^{\text {a }}\end{array}$ & Species & $\begin{array}{l}\text { Archaeological } \\
\text { phases }\end{array}$ & $\begin{array}{l}{ }^{14} \mathrm{C} \text { age } \\
\text { (yr BP) }\end{array}$ \\
\hline LTL1421A & 49 & $\mathrm{a}$ & Vicia faba var. minor & Appenninic & $2920 \pm 45$ \\
\hline LTL1422A & 50 & $\mathrm{~b}$ & Triticum dicoccum & Appenninic & $2969 \pm 60$ \\
\hline LTL1425A & 103 & c & Olea europaea & Proto-Appenninic & $2971 \pm 55$ \\
\hline LTL1423A & 85 & $\mathrm{~d}$ & T. dicoccum & Proto-Appenninic & $3112 \pm 30$ \\
\hline LTL1426A & 266 & e & O. europaea & Pianoconte & $4200 \pm 65$ \\
\hline LTL1427A & 282 & $\mathrm{f}$ & O. europaea & Pianoconte & $4622 \pm 85$ \\
\hline LTL1429A & 310 & g & O. europaea & Spatarella-Diana & $5109 \pm 50$ \\
\hline LTL1431A & $312 \mathrm{C}$ & $\mathrm{h}$ & O. europaea & Spatarella-Diana & $5221 \pm 60$ \\
\hline LTL2154A & 370 & $\mathrm{i}$ & Seeds & Bande Rosse & $6229 \pm 55$ \\
\hline LTL2156A & 373 & l & Seeds & Bande Rosse & $6432 \pm 60$ \\
\hline LTL3578A & 1025 & - & Charcoal & Mesolithic & $8963 \pm 60$ \\
\hline
\end{tabular}

${ }^{a}$ Refer to Figure 2 for sampling positions.

\section{RESULTS}

AMS measurement results are shown as uncalibrated ${ }^{14} \mathrm{C}$ ages in Table 1 . One can see that the uncertainties obtained for some of the measurements are larger than those achievable at CEDAD in routine measurements of samples of standard mass ( $1 \mathrm{mg} C$ ). This was due to the poor ${ }^{14} \mathrm{C}$ counting statistics achieved for low-mass samples $(\leq 0.5 \mathrm{mg} \mathrm{C})$. Conventional ${ }^{14} \mathrm{C}$ ages were then converted to calendar ages using the IntCal04 atmospheric calibration data set (Reimer et al. 2004) and OxCal 4.0 software (Bronk Ramsey 1995, 2001). The obtained ages show occupation phases spanning from the early 9th millennium cal BC (Mesolithic) to the 11th-12th centuries cal BC (Bronze Age). 
The available ${ }^{14} \mathrm{C}$ data were also used to construct a chronological model by using the Sequence function in OxCal. The different ages were grouped into different phases defined on the basis of typological analysis of associated archaeological material. The sequence of the different archaeological phases was then established according to the position of the different cultural layers in the cave stratigraphy. Results of this analysis are shown in Figure 3. The calculated index of agreement (A) of the individual measurements ranged between 85.8 and 108.9\%, indicating good agreement between the data and the model. Similarly, an overall agreement index $\left(A_{\text {model }}\right)$ of $94.3 \%$ was obtained, well above the threshold of $60 \%$, indicating a good consistency between the $a$ priori supposed model and the set of data. Calibrated time ranges for all the samples and the defined Boundaries are listed in Table 2.

Table 2 Calibrated time ranges for the single samples and age boundaries obtained using the OxCal model.

\begin{tabular}{|c|c|c|}
\hline Archaeological phases & Sample & $\begin{array}{l}\text { Calibrated date ranges (cal BC, } \\
\text { posterior distributions) }\end{array}$ \\
\hline Boundary End Appenninic & Boundary & 1201-992 (68.2\%) \\
\hline Appenninic & LTL1421A & 1212-1076 (68.2\%) \\
\hline Appenninic & LTL1422A & $\begin{array}{l}1244-1110 \text { (64.8\%); } \\
1101-1091(3.4 \%)\end{array}$ \\
\hline Boundary Proto-Appenninic-Appenninic & Boundary & $1301-1149$ (68.2\%) \\
\hline Proto-Appenninic & LTL1425A & $\begin{array}{l}1379-1338(21.0 \%) ; \\
1319-1230(47.2 \%)\end{array}$ \\
\hline Proto-Appenninic & LTL1423A & $\begin{array}{l}1424-1377(45.4 \%) \\
1341-1318(22.8 \%)\end{array}$ \\
\hline Boundary Start Proto-Appenninic & Boundary & $1584-1323(68.2 \%)$ \\
\hline Boundary End Pianoconte & Boundary & $\begin{array}{l}2832-2177(67.3 \%) \\
2169-2155(0.9 \%)\end{array}$ \\
\hline Pianoconte & LTL1426A & $\begin{array}{l}2900-2836(26.9 \%) ; \\
2816-2737(30.5 \%) ; \\
2731-2696(10.8 \%)\end{array}$ \\
\hline Pianoconte & LTL1427A & $\begin{array}{l}\text { 3519-3331 (50.4\%); } \\
\text { 3218-3176 (8.7\%); } \\
3160-3117 \text { (9.1\%) }\end{array}$ \\
\hline Boundary Spatarella-Diana-Pianoconte & Boundary & $3956-3581(68.2 \%)$ \\
\hline Spatarella-Diana & LTL1429A & $\begin{array}{l}3976-3915(38.2 \%) ; \\
3875-3813(30.0 \%)\end{array}$ \\
\hline Spatarella-Diana & LTL1431A & $4068-3955(68.2 \%)$ \\
\hline Boundary Start Spatarella-Diana & Boundary & $4381-3969(68.2 \%)$ \\
\hline Boundary End Bande Rosse & Boundary & 5295-4891 (68.2\%) \\
\hline Bande Rosse & LTL2154A & $\begin{array}{l}\text { 5312-5201 (58.9\%); } \\
\text { 5170-5138 (9.3\%) }\end{array}$ \\
\hline Bande Rosse & LTL2156A & $5433-5318(68.2 \%)$ \\
\hline Boundary Start Bande Rosse & Boundary & $5608-5321(68.2 \%)$ \\
\hline Mesolithic & LTL3578A & $\begin{array}{l}\text { 8274-8181 (38.4\%); } \\
\text { 8113-8090 (7.7\%); } \\
\text { 8076-8061 (4.6\%); } \\
\text { 8043-7994 (17.5\%) }\end{array}$ \\
\hline
\end{tabular}




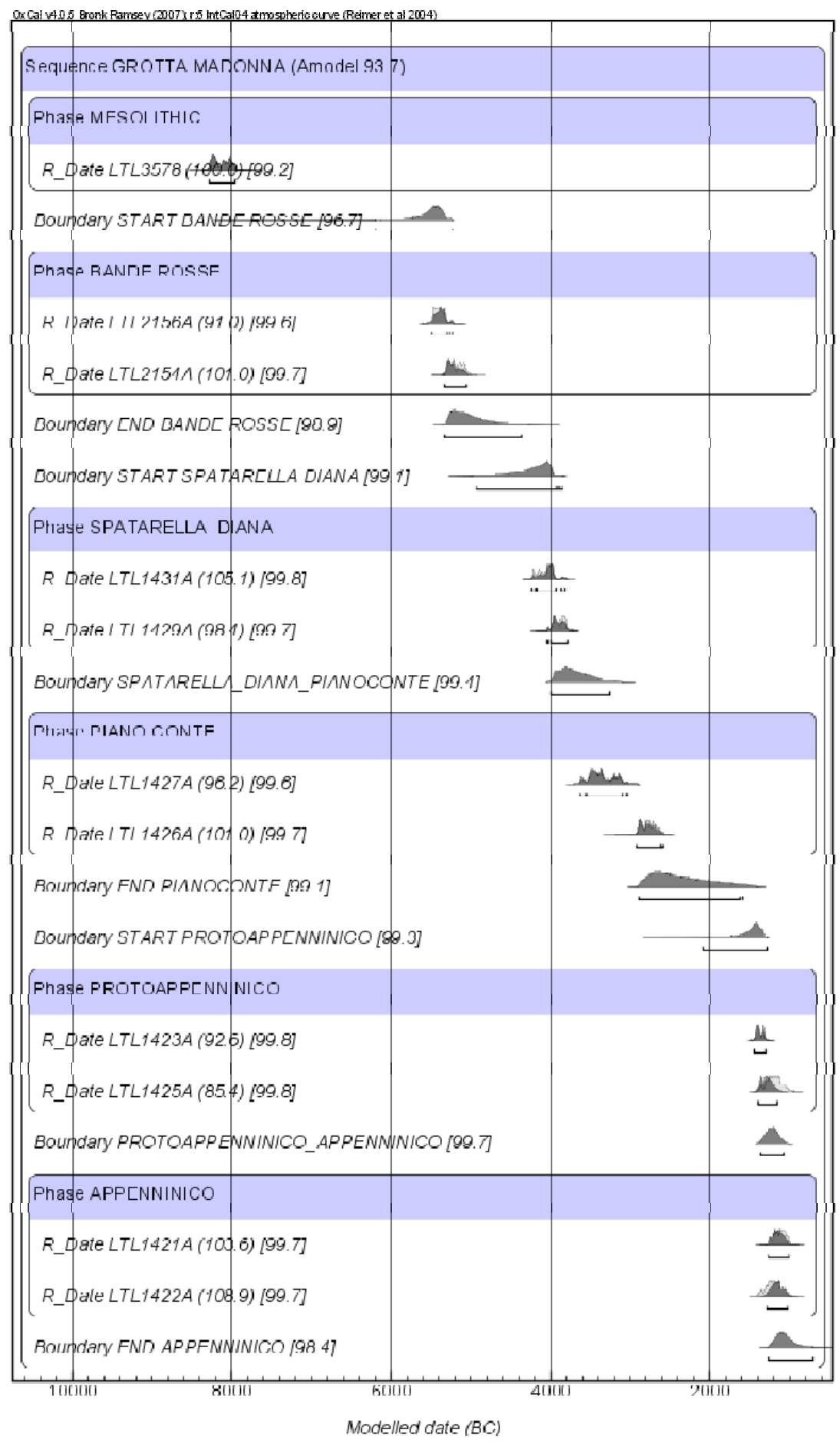

Figure 3 Modeled analysis of the "Santuario della Madonna” cave stratigraphic sequence 
According to the results of the model, the following chronological timeframe was established for the different cultural aspects identified in the cave:

a. "Red Stripes" (Bande Rosse) pottery (Middle Neolithic): second half of the 6th millennium BC;

b. Spatarella-Diana (Late Neolithic): end of 5th to beginning of 6th millennium BC;

c. Pianoconte style (Early Chalcolithic): second half of 4th to first half of 3rd millennium BC;

d. Proto-Appenninic (Middle Bronze Age, phases 1-2): 12th-14th centuries BC;

e. Appenninic (Middle Bronze Age, phase 3): 11th-12th centuries BC.

\section{CONCLUSIONS}

${ }^{14} \mathrm{C}$ dating analyses carried out on short-lived vegetal remains from the stratigraphic sequence of the "Santuario della Madonna" Cave in Praia a Mare, southern Italy, confirmed the archaeological evidence showing a stratigraphy spanning from the Mesolithic to the Bronze Age. The analysis allowed first of all to reconstruct the stratigraphy of the studied cave, allowing to obtain a chronological framework for the different cultural horizons identified based on the archaeological material. The obtained results can be thus considered significant for the definition of an absolute timeframe for the chronology southern Italian prehistory.

\section{REFERENCES}

Bayliss A. 2009. Rolling out revolution: using radiocarbon dating in archaeology. Radiocarbon 51(1):123 47.

Bronk Ramsey C. 1995. Radiocarbon calibration and analysis of stratigraphy: the OxCal program. Radiocarbon 37(2):425-30.

Bronk Ramsey C. 2001. Development of the radiocarbon calibration program. Radiocarbon 43(2A):355-63.

Bronk Ramsey C. 2009. Bayesian analysis of radiocarbon dates. Radiocarbon 51(1):337-60.

Buck CE, Kenworthy JB, Litton CD, Smith AFM. 1991. Combining archaeological and radiocarbon information: a Bayesian approach to calibration. Antiquity 65(249):808-21.

Calcagnile L, Quarta G, D’Elia M, Rizzo A, Gottdang A, Klein M, Mous DJW. 2004. A new accelerator mass spectrometry facility in Lecce, Italy. Nuclear Instruments and Methods in Physics Research B 223-224: 16-20.

Calcagnile L, Quarta G, D’Elia M. 2005. High resolution accelerator-based mass spectrometry: precision, accuracy and background. Applied Radiation and Isotopes 62(4):623-9.
D’Elia M, Calcagnile L, Quarta G, Rizzo A, Sanapo C, Laudisa M, Toma U, Rizzo A. 2004. Sample preparation and blank values at the AMS radiocarbon facility of the University of Lecce. Nuclear Instruments and Methods in Physics Research B 223-224:278-83.

Pessina A, Tinè V. 2008. Archeologia del neolitico: l'Italia tra VI e IV millennio a.C. Rome: Carocci Editore. 375 p. In Italian.

Reimer PJ, Baillie MGL, Bard E, Bayliss A, Beck JW, Bertrand CJH, Blackwell PG, Buck CE, Burr GS, Cutler KB, Damon PE, Edwards RL, Fairbanks RG, Friedrich M, Guilderson TP, Hogg AG, Hughen KA, Kromer B, McCormac G, Manning S, Bronk Ramsey C, Reimer RW, Remmele S, Southon JR, Stuiver M, Talamo S, Taylor FW, van der Plicht J, Weyhenmeyer CE. 2004. IntCal04 terrestrial radiocarbon age calibration, 0-26 cal kyr BP. Radiocarbon 46(3):1029-58.

Skeates R, Whitehouse R, editors. 1994. Radiocarbon Dating and Italian Prehistory. Archeological Monograph of the British School at Rome 8. Rome: British School at Rome.

Stuiver M, Polach HA. 1977. Discussion: reporting of ${ }^{14} \mathrm{C}$ data. Radiocarbon 19(3):355-63. 